\title{
PENGARUH ENVIRONMENTAL RISK TERHADAP KINERJA KEUANGAN PERUSAHAAN \\ (Studi pada perusahaan-perusahaan di Indonesia, Singapura, Malaysia, Thailand, Filipina dan Vietnam)
}

\author{
Nila Firdausi Nuzula ${ }^{1}$, Cacik Rut Damayanti ${ }^{2}$, Sri Sulasmiyati ${ }^{3}$ \\ Fakultas Ilmu Administrasi, Universitas Brawijaya \\ Email: $\underline{\text { nilafia@ub.ac.id }}{ }^{1}, \underline{\text { cacik@ub.ac.id }}^{2}, \underline{\text { sri_su_fia@ub.ac.id }^{3}}$
}

\begin{abstract}
ABSTRAK
The purpose of this study was to find out how the influence of environmental risk on profitability and the value of companies that are publicly listed on stock exchanges in Indonesia, Malaysia, Singapore, Thailand, the Philippines and Vietnam. This study uses secondary data for all variables, namely utilizing data from Osiris Financial Database, which includes 558 companies from these six countries. The results of the study show that environmental risk is not proven to affect financial performance, both for accounting or market-based financial indicators in Indonesia, Malaysia, Singapore, Thailand and the Philippines. Environmental risk proved to significantly affect Price to Earnings Ratio in Vietnam, both in testing univariate and multivariate regression models with several control variables. However, in multivariate testing by including control variables, it is evident that environmental risk has a real impact on achieving ROA in Singapore and Thailand, on ROE in Malaysia and Vietnam, on PER in Thailand and Vietnam, and Tobin's $Q$ on companies in Indonesia, Malaysia, and Thailand. Multivariate testing with combined data from six countries shows that environmental risk together contributes significantly to achieving ROA and PER. Control variables that contribute to the significant influence are industry type, country of origin, and size of the company.
\end{abstract}

Keywords: environmental risk, Profitability, Companies Value, ASEAN countries

\begin{abstract}
ABSTRAK
Tujuan penelitian ini adalah untuk mengetahui bagaimana pengaruh environmental risk terhadap profitabilitas dan nilai perusahaan yang terdaftar secara public di bursa efek di Indonesia, Malaysia, Singapura, Thailand, Filipina, dan Vietnam. Penelitian ini menggunakan data sekunder untuk seluruh variabel, yaitu memanfaatkan data dari Osiris Financial Database, yang meliputi 558 perusahaan dari enam negara tersebut. Hasil penelitian menunjukkan bahwa risiko lingkungan tidak terbukti dapat mempengaruhi kinerja keuangan, baik untuk indikator keuangan berbasis akuntansi ataupun berbasis pasar di Indonesia, Malaysia, Singapura, Thailand, dan Filipina. Risiko lingkungan terbukti signifikan mempengaruhi Price to Earnings Ratio di Vietnam, baik pada pengujian model regresi univariat maupun multivariate dengan beberapa variabel kontrol. Akan tetapi, pada pengujian secara multivariate dengan memasukkan variabel kontrol, terbukti bahwa environmental risk berdampak nyata pada pencapaian ROA di Singapura dan Thailand, terhadap ROE di Malaysia dan Vietnam, terhadap PER di Thailand dan Vietnam, serta Tobin's Q pada perusahaan di Indonesia, Malaysia, dan Thailand. Pengujian multivariate dengan data gabungan dari ke enam negara menunjukkan bahwa environmental risk secara bersama-sama berkontribusi nyata untuk mencapai ROA dan PER. Variabel kontrol yang berkontribusi atas terjadinya pengaruh signifikan tersebut adalah tipe industri, asal negara, dan ukuran perusahaan.
\end{abstract}

Kata Kunci: environmental risk, Profitabilitas, Nilai perusahaan, Negara ASEAN 


\section{PENDAHULUAN}

Seiring dengan peningkatan laju pertumbuhan ekonomi, eksploitasi sumber daya lingkungan semakin tinggi pula. Perusahaan mengalami risiko sosial dan lingkungan yang dihadapi perusahaan besar dan multinasional karena ketidakmampuan mengintegrasikan masalah sosial dan lingkungan dalam kegiatan bisnis sehari-hari. Dalam konteks bisnis, risiko sosial dan lingkungan ini dikategorikan sebagai bagian dari non-financial risk, sementara risiko lingkungan meliputi potensi terjadinya kerugian finansial akibat kekurangmampuan untuk mengelola sumber daya perusahaan. Coulson \& Dixon (1995) menyatakan bahwa eksternalitas negatif atas aktifitas manusia pada lingkungan alam telah makin nyata, didukung dengan pernyataan para ahli bahwa pemanasan global telah menjadi tantangan semua pihak. Sebagai dampaknya, aktifitas bisnis telah menjadi subjek bagi pemerintah dan pelaku pasar dimana kedua institusi ini mendorong organisasi bisnis untuk mengadopsi strategi lingkungan yang akan mampu mengurangi dampak lingkungan di masa datang.

Menurut Wong (2014), secara umum pengelolaan risiko dapat dikategorikan dalam dua jenis, yaitu financial risk dan non-financial risk management. Pengelolaan risiko keuangan atau financial risk management meliputi berbagai hal yang berkaitan dengan arus kas, seperti pengelolaan risiko penurunan jumlah piutang, pengelolaan kerugian pembayaran transaksi mata uang asing, dan sebagainya. Sementara, yang termasuk non-financial risk management atau pengelolaan risiko non keuangan termasuk pengelolaan risiko karena ketidakmampuan mengelola masalah limbah dan hak-hak asasi pekerja.

Christmann (2000) menganalisis pengaruh risiko lingkungan terhadap kinerja dan nilai perusahaan, seperti apakah jika penggunaan teknologi yang mampu mencegah polusi dapat berdampak pada peningkatan besarnya cost advantage yang diperoleh asesor internal dari penerapan strategi lingkungan dan apakah jika kemampuan perusahaan memiliki tingkat inovasi teknologi pencegah polusi dapat berdampak pada makin besarnya cost advantage yang diperoleh dari strategi lingkungan. Penelitian dilakukan terhadap perusahaan kimia di Amerika pada tahun 19911994 dengan data berasal dari Toxics Release Inventory (TRI) yang dikeluarkan oleh Environmental Protection Agency (EPA) Amerika
Serikat. Hasil penelitian menunjukkan bahwa praktik manajemen lingkungan perusahaan secara umum tidak mampu membawa perusahaan untuk mencapai cost advantage, dan meragukan konsepsi bahwa praktik pengelolaan lingkungan dapat mencapai tingkat keunggulan bersaing yang lebih baik. Coulson \& Dixon (1995) menulis artikel yang memfokuskan untuk menjelaskan mengapa perusahaan perlu mengintegrasikan pertimbangan dan masalah lingkungan dengan strategi perusahaan. Pertama, sektor keuangan dan perbankan saat ini telah menunjukkan atensi dan respek terhadap perusahaan yang memiliki komitmen untuk memenuhi tanggung jawab terhadap lingkungannya. Kedua, terdapat kecenderungan bahwa kreditur memantau kinerja perusahaan termasuk dari sudut pandang kemampuannya mengatasi polusi yang ditimbulkan dari aktifitas operasional perusahaan. Ketiga, terdapat kecenderungan adanya "ethical investment" atau "green fund" dimana investor menyusun portofolio investasi dari perusahaanperusahaan publik yang menunjukkan komitmen terhadap upaya pelestarian lingkungan secara nyata.

Penelitian ini bermaksud mengkaji pengaruh besarnya environmental risk terhadap kinerja keuangan perusahaan. Peneliti mengklasifikasikan kinerja keuangan ke dalam dua kategori, yaitu accounting- dan market-based performance. Pembedaan ini menarik untuk dikaji karena menurut Said, HassabElnaby, \& Wier (2003) keduanya memiliki pendekatan berbeda dan dengan demikian menghasilkan informasi yang berbeda. Selanjutnya peneliti menganalisis dampak environmental risk terhadap dua indikator accounting-based performance, yaitu Return on Assets (ROA) dan Return on Equity (ROE), dan dampaknya terhadap dua indikator market-based performance yaitu Price to Earnings Ratio (PER) dan Tobin's Q. Penelitian ini dilakukan di perusahaan-perusahaan yang terdaftar di bursa 6 (enam) Negara yaitu Indonesia, Malaysia, Singapura, Thailand, Filipina, Vietnam. Peneliti berasumsi bahwa kondisi 6 (enam) negara ASEAN tersebut berbeda sehingga perlu dibuktikan secara empiris.

Berdasarkan latar belakang tersebut di atas, rumusan masalah penelitian ini adalah sebagai berikut.

1. Apakah environmental risk berpengaruh terhadap ROA di enam negara ASEAN? 
2. Apakah environmental risk, bersama-sama dengan variabel kontrol yaitu tipe industri dan ukuran perusahaan, berpengaruh terhadap ROA di enam negara ASEAN?

3. Apakah environmental risk berpengaruh terhadap ROE di enam negara ASEAN?

4. Apakah environmental risk, bersama-sama dengan variabel kontrol yaitu tipe industri dan ukuran perusahaan, berpengaruh terhadap ROE di enam negara ASEAN?

5. Apakah environmental risk berpengaruh terhadap PER di enam negara ASEAN?

6. Apakah environmental risk, bersama-sama dengan variabel kontrol yaitu tipe industri dan ukuran perusahaan, berpengaruh terhadap PER di enam negara ASEAN?

7. Apakah environmental risk berpengaruh terhadap Tobin's q di enam negara ASEAN?

8. Apakah environmental risk, bersama-sama dengan variabel kontrol yaitu tipe industri dan ukuran perusahaan, berpengaruh terhadap Tobin's q di enam negara ASEAN?

9. Apakah environmental risk, bersama-sama dengan variabel kontrol yaitu tipe industri, ukuran perusahaan dan negara berpengaruh terhadap ROA di seluruh negara ASEAN?

10. Apakah environmental risk, bersama-sama dengan variabel kontrol yaitu tipe industri, ukuran perusahaan dan negara berpengaruh terhadap ROE di seluruh negara ASEAN?

11. Apakah environmental risk, bersama-sama dengan variabel kontrol yaitu tipe industri, ukuran perusahaan dan negara berpengaruh terhadap PER di seluruh negara ASEAN?

12. Apakah environmental risk, bersama-sama dengan variabel kontrol yaitu tipe industri, ukuran perusahaan dan negara berpengaruh terhadap Tobin's q di seluruh negara ASEAN?

Dalam penelitian ini, teori yang digunakan adalah Resource-Based View (RBV) dan institutional theory. RBV merupakan bagian dari pendekatan manajemen strategis, dimana manajer perusahaan memiliki kepentingan strategis untuk mengimplementasikan isu lingkungan dalam kegiatan bisnis sehari-hari. Menurut teori ini, tidak seluruh perusahaan memiliki kapasitas untuk menciptakan keunggulan kompetitif dari upayanya mengimplementasikan strategi bisnis yang berwawasan lingkungan dan isu keberlanjutan (sustainability issues) (Christmann, 2000). Perusahaan perlu memusatkan perhatian pada aspek-aspek bisnis dan bersedia untuk mengeluarkan dana tertentu yang dapat berkontribusi untuk memacu tingkat kompetisi perusahaan (firms' competitiveness level). Konsep RBV menitikberatkan pada analisis sejauh mana asset yang dimiliki perusahaan saat ini mampu mendukung implementasi manajemen lingkungan (environmental management) dan menjaga tingkat kemampuan bersaing suatu perusahaan (Christmann, 2000).

Dalam Institutional theory, evaluasi dan perhitungan risiko lingkungan dan social perlu mempertimbangkan karakter spesifik perusahaan dan industri dimana perusahaan tersebut beroperasi (Christmann, 2000). Sebagai bagian dari manajemen risiko atas aspek non-keuangan, implementasi konsep manajemen risiko lingkungan menjadi semakin kompleks karena perlu menyeimbangkan berbagai kondisi, perspektif dan indicator kinerja dari berbagai sisi internal suatu organisasi. Berbeda dari RBV yang menekankan aspek internal sebagai factor pendorong mengapa perusahaan dapat terlibat dalam upaya-upaya pengelolaan lingkungan dan social, institutional theory lebih menekankan pada keberadaan aspek eksternal yang mempengaruhi bagaimana suatu organisasi dijalankan. Institutional theory merujuk pada berbagai peraturan, norma dan consensus yang ada pada suatu kelompok atau negara, yang bersifat kolektif dan disepakati bersama, dan dikontrol oleh agen politik dan social, dan keberadaannya mendominasi organisasi bisnis (Man, 2010).

Wong (2014) menyatakan bahwa jika perusahaan mampu mengidentifikasi dan mengelola risiko non-keuangan (non-financial risk), seperti risiko lingkungan dan social, maka perusahaan akan mampu menemukan kesempatan dan solusi baru, dan akhirnya mampu meningkatkan nilai perusahaan di mata pemegang saham. Menurut Christmann (2000), aset dan sumber daya yang dimiliki perusahaan mampu mendukung implementasi pengelolaan dan pelestarian lingkungan sedemikian rupa sehingga risiko bisnis yang berkaitan dengan lingkungan hidup dapat berkurang. Menurut Porter (1995), keunggulan kompetitif dapat dipacu melalui biaya (cost) dan atau keunggulan karena mampu melakukan diferensiasi (differentiation advantage). Dalam kerangka ini, maka strategi pengelolaan lingkungan oleh perusahaan dapat mengarahkan perusahaan untuk mencapai 
keunggulan kompetitif melalui aspek keunggulan biaya (cost advantage). Selain pengurangan biaya dalam tahap proses produksi, efisiensi dapat dicapai karena pengurangan biaya pengelolaan perusahaan, seperti berkurangnya biaya yang wajib dikeluarkan perusahaan misalnya dikenakannya denda karena kegagalan perusahaan mengelola lingkungan (potential liability costs), biaya yang berkaitan dengan masalah hukum (legal fees), biaya karena pengembalian produk atau produk gagal (potential product-take-back cost).

Penelitian ini didasarkan pada konsep bahwa kemampuan perusahaan untuk mengkapitalisasikan keuntungan dari upaya mengelola risiko lingkungan, ditentukan dari karakteristik industri dimana perusahaan beroperasi. Terdapat jenis-jenis industri yang dikategorikan sebagai industri yang memiliki risiko lingkungan tinggi, dan sebaliknya, sehingga model hipotesis yang dikembangkana adalah sebagai berikut:

Model Hipotesis I

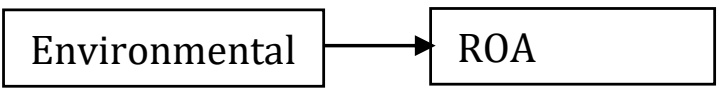

Model Hipotesis II

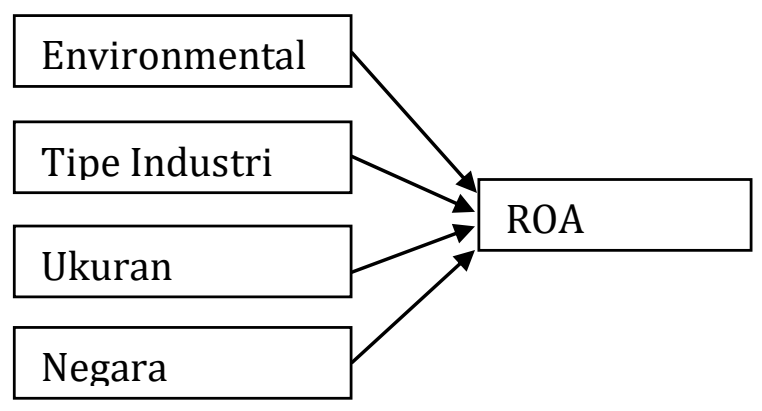

Model Hipotesis III

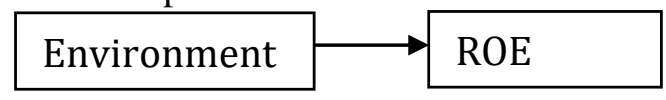

Model Hipotesis IV

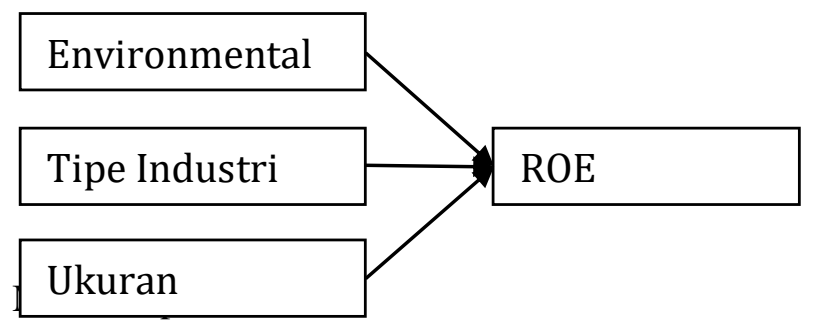

\begin{tabular}{|l|l}
\hline Environmental & PER \\
\hline
\end{tabular}

Model Hipotesis VI

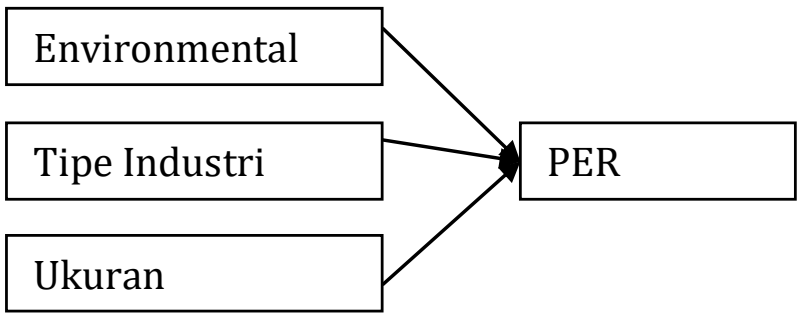

Model Hipotesis VII

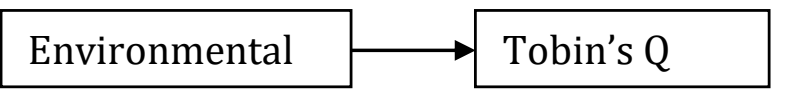

Model Hipotesis VIII

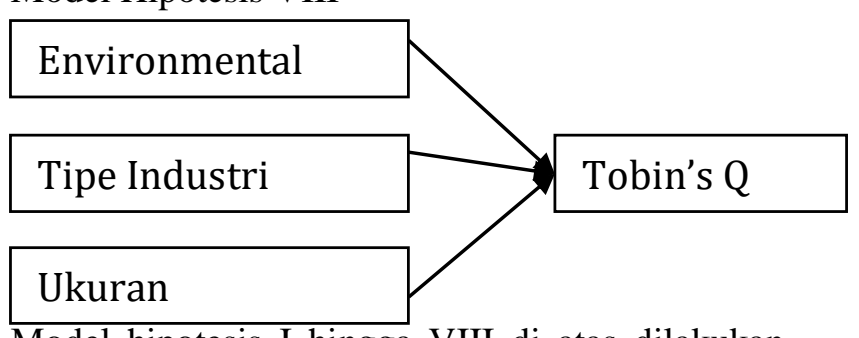

Model hipotesis I hingga VIII di atas dilakukan untuk setiap negara. Kemudian, untuk model hipotesis IX-XII dianalisis dengan menggabungkan data seluruh negara. Karena peneliti ingin mengetahui bagaimana kontribusi negara terhadap kinerja keuangan perusahaan, maka pada model hipotesis IX-XII terdapat penambahan pada variabel kontrolnya.

Model Hipotesis IX

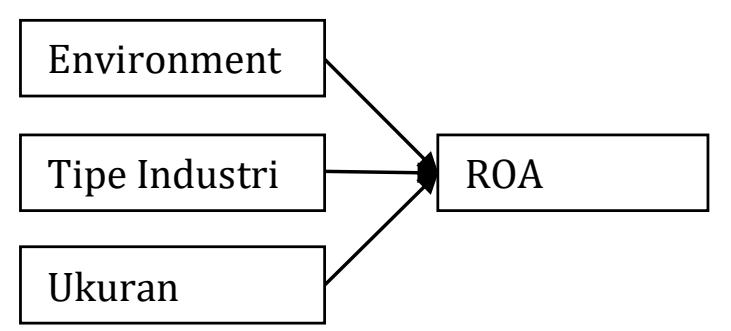

Model Hipotesis X

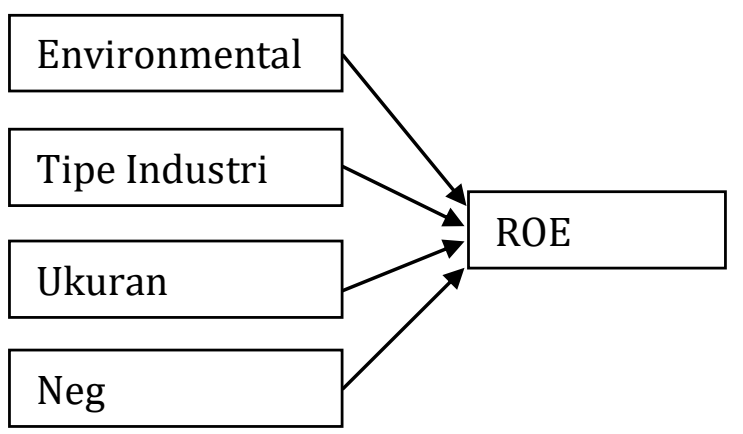


Model Hipotesis XI
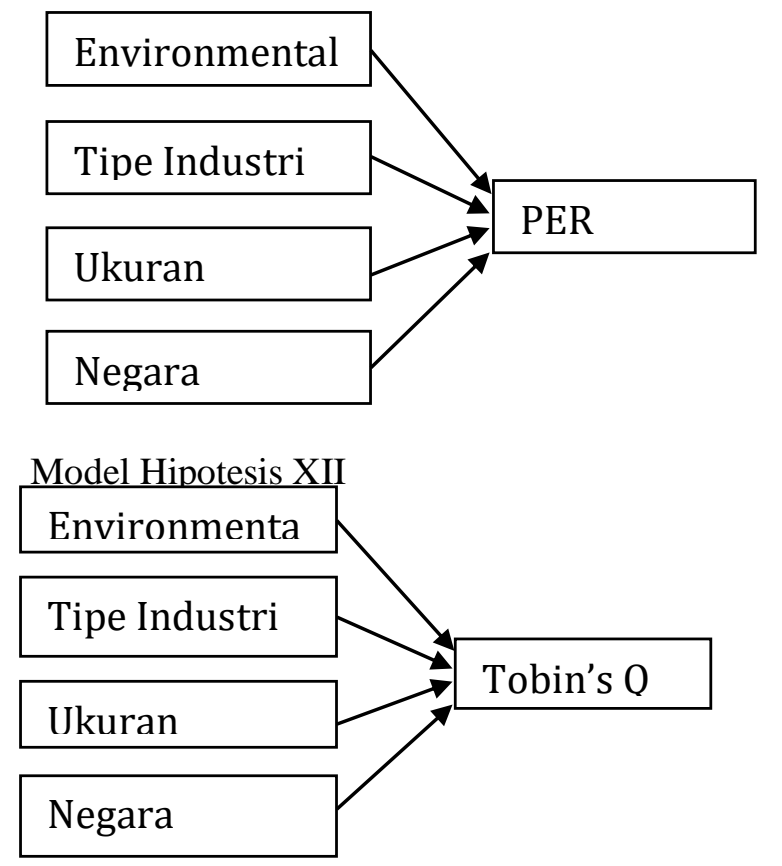

Dengan merujuk pada ke delapan model tersebut di atas, maka pernyataan hipotesis nol $\left(\mathrm{H}_{0}\right)$ pada penelitian ini adalah sebagai berikut.

H1 Environmental risk berpengaruh terhadap ROA

$\mathrm{H} 2$ Environmental risk, bersama-sama dengan variabel kontrol yaitu tipe industri dan ukuran perusahaan, berpengaruh terhadap ROA?

H3 Environmental risk berpengaruh terhadap ROE?

H4 Environmental risk, bersama-sama dengan variabel kontrol yaitu tipe industri dan ukuran perusahaan, berpengaruh terhadap ROE?

H5 Environmental risk berpengaruh terhadap PER?

H6 Environmental risk, bersama-sama dengan variabel kontrol yaitu tipe industri dan ukuran perusahaan, berpengaruh terhadap PER?

$\mathrm{H} 7$ Environmental risk berpengaruh terhadap Tobin's q?

H8 Environmental risk, bersama-sama dengan variabel kontrol yaitu tipe industri dan ukuran perusahaan, berpengaruh terhadap Tobin's q?

H9 Environmental risk, bersama-sama dengan variabel kontrol yaitu tipe industri, ukuran perusahaan dan negara berpengaruh terhadap ROA?
H10 Environmental risk, bersama-sama dengan variabel kontrol yaitu tipe industri, ukuran perusahaan dan negara berpengaruh terhadap ROE?

H11 Environmental risk, bersama-sama dengan variabel kontrol yaitu tipe industri, ukuran perusahaan dan negara berpengaruh terhadap PER?

H12 Environmental risk, bersama-sama dengan variabel kontrol yaitu tipe industri, ukuran perusahaan dan negara berpengaruh terhadap Tobin's q?

\section{METODE PENELITIAN}

Jenis penelitian ini adalah penelitian eksplanatoris (explanatory research) dengan pendekatan kuantitatif. Jenis penelitian ini digunakan untuk menjelaskan bagaimana pengaruh environmental risk terhadap variabel dependen, yaitu profitabilitas dan nilai perusahaan, dengan mempertimbangkan adanya variabel kontrol yaitu jenis industri, ukuran perusahaan dan negara. Data yang digunakan dalam penelitian ini adalah data sekunder yang diambil dari Osiris (www.osiris.bvdinfo.com) dan website perusahaan.

Terdapat enam variabel yang dianalisa dalam penelitian ini dengan pengukuran yang berbeda. Environmental risk diukur dengan menggunakan rasio yang diterbitkan oleh Osiris Financial Database, profitabilitas diukur dengan menggunakan return on equity ratio (ROE) dan return on asset (ROA) dan variable nilai perusahaan diukur dengan menggunakan price to earnings ratio (PER) dan Tobin's q. Variable jenis industri diukur berdasarkan klasifikasi jenis industri pada Bursa Efek Indonesia. Variabel ini dikuantifikasi dengan cara memberikan notasi. Pemberian notasi string dilakukan oleh software gretl.Variabel ukuran perusahaan dihitung dari besarnya nilai aset total dalam satu tahun. Untuk kepentingan uji hipotesis, peneliti menggunakan nilai ukuran perusahaan yang telah ditransformasi menggunakan natural logaritma. Dalam analisis Ordinary Least Square (OLS), proksi untuk negara akan ditentukan oleh secara otomatis oleh software gretl® yaitu dengan memposisikan nama-nama negara tersebut pada nilai string.

Teknik analisis data dalam penelitian ini meliputi cara mengelompokkan data berdasarkan variabel dan jenis responden, mentabulasi data berdasarkan variabel, menyajikan data setiap variabel yang diteliti dengan menggunakan analisis 
statistik deskriptif. Untuk menjawab hipotesis penelitian, penelitian ini menggunakan regresi linear berganda.

\section{HASIL PENELITIAN DAN DISKUSI}

Total observasi data yang digunakan dalam analisis mencakup 1662 unit analisis. Tabel 1 menjelaskan prosentase perusahaan sampel dari masing-masing negara dan table 2 menjelaskan deskriptif statistik dari data penelitian.

\section{Table 1 Data jumlah sampel perusahaan dari 6}

negara
\begin{tabular}{|c|c|c|c|}
\hline No & Negara & $\begin{array}{c}\text { Jumlah } \\
\text { perusahaan }\end{array}$ & $\begin{array}{c}\text { Proporsi } \\
\text { perusahaan } \\
\text { sampel }\end{array}$ \\
\hline 1 & Indonesia & 72 & $12,90 \%$ \\
\hline 2 & Malaysia & 165 & $29,57 \%$ \\
\hline 3 & Singapore & 81 & $14,52 \%$ \\
\hline 4 & Thailand & 112 & $20,07 \%$ \\
\hline 5 & Philippines & 15 & $2,69 \%$ \\
\hline 6 & Vietnam & 113 & $20,25 \%$ \\
\hline \multicolumn{2}{|c|}{$\begin{array}{c}\text { Total jumlah } \\
\text { perusahaan }\end{array}$} & 558 & $100 \%$ \\
\hline
\end{tabular}

Sumber: Data Osiris diolah (2018)

Table 2 Statistik deskriptif perusahaanperusahaan sampel di 6 negara

\begin{tabular}{|l|r|r|r|r|r|r|}
\hline Keterangan & $\begin{array}{r}\text { ROA } \\
(\%)\end{array}$ & $\begin{array}{r}\text { ROE } \\
(\%)\end{array}$ & $\begin{array}{r}\text { PER } \\
(\%)\end{array}$ & $\begin{array}{r}\text { Total } \\
\text { Asset } \\
\text { (USD) }\end{array}$ & $\begin{array}{r}\text { Env. } \\
\text { Risk } \\
(\%)\end{array}$ & $\begin{array}{r}\text { Tobin's } \\
\mathbf{Q}(\%)\end{array}$ \\
\hline $\begin{array}{l}\text { Nilai } \\
\text { Maksimum }\end{array}$ & 75.40 & 666.25 & 839.37 & $46,631,795.00$ & 142.94 & 17.95 \\
\hline $\begin{array}{l}\text { Nilai } \\
\text { Minimum }\end{array}$ & 0.04 & 0.05 & 0.00 & 996.52 & 0.88 & 0.00 \\
\hline Rata-rata & 7.50 & 12.96 & 19.74 & $701,162.11$ & 8.47 & 1.02 \\
\hline $\begin{array}{l}\text { Standar } \\
\text { Deviasi }\end{array}$ & 6.693 & 20.520 & 42.656 & 2965455.231 & 12.795 & 1.456 \\
\hline
\end{tabular}

Sumber: Data Osiris diolah, 2018

Tabel 3 dan Tabel 4 menunjukkan hasil uji pada variabel-variabel pada accounting-based dan market-based financial performances. Model 1 untuk all countries menunjukkan bahwa environmental risk tidak berpengaruh pada ROA. Akan tetapi, pada Model 2 dimana peneliti memasukkan variabel kontrol, uji OLS membuktikan bahwa keberadaan variabel kontrol mampu membawa variabel environmental risk berpengaruh secara bersama-sama terhadap ROA dengan $p$ value sebesar 0,00252 ( $p$ value $<0,05$ ). Kontribusi variabel kontrol terutama ditunjukkan oleh variabel tipe industri dimana $\mathrm{p}$ value parsial variabel tersebut adalah 0,0043 ( $\mathrm{p}$ value $<0,05$ ). Hasil uji Model 5 menunjukkan bahwa data variabel environmental risk tidak mampu memberikan pengaruh nyata pada Tobin's q secara univariat. Pada Model 6 dimana terdapat variabel kontrol sebagai variabel regressor, hasil uji pada semua negara menunjukkan bahwa tipe industri, ukuran perusahaan, dan asal negara (country of origin) memiliki pengaruh nyata terhadap terbentuknya Tobin's q. Akan tetapi kontribusi ketiga variabel kontrol tersebut ternyata tidak mampu menjadikan environmental risk berpengaruh pada Tobin's q. Selanjutnya, untuk market-based performance dengan proksi PER, environmental risk terbukti tidak berpengaruh secara nyata yaitu dengan $\mathrm{p}$ value sebesar 0,6953 ( $\mathrm{p}$ value $>0,05)$. Tetapi, dengan variabel kontrol sebagai regressor sebagaimana disebutkan pada Model 8, terbukti bahwa secara bersama-sama environmental risk berdampak nyata pada PER yaitu dengan $\mathrm{p}$ value sebesar 0,01298 ( $\mathrm{p}$ value < $0,05)$. Kontribusi variabel kontrol terutama ditunjukkan oleh keberadaan negara asal perusahaan dengan $\mathrm{p}$ value sebesar 0,0006 ( $\mathrm{p}$ value $<0,05)$.

\subsection{Pengaruh environmental risk secara individual terhadap financial performance}

Hasil penelitian menunjukkan bahwa di seluruh negara tidak terdapat bukti signifikan bahwa environmental risk berpengaruh terhadapaccounting-based financial performance secara individual. Pada kasus pengaruh environmental risk terhadap market-based financial performance, ditemukan satu kasus bahwa variabel independen tersebut berpengaruh pada PER secara individual, yaitu pada Model $7 \mathrm{di}$ Vietnam. Ringkasan hasil uji hipotesis untuk model-model OLS di mana environmental risk ditemukan berpengaruh secara nyata terhadap kinerja keuangan perusahaan di seluruh negaranegara ASEAN disajikan dalam tabel 5.

Hasil uji pengaruh environmental risk secara univariate atau individual terhadap ROA, ROE, Tobin's q, dan PER di seluruh negara hampir tidak ditemukan adanya hasil yang signifikan, kecuali di Vietnam yaitu untuk Model 7. Hasil ini menunjukkan bahwa pelaku pasar saham di Vietnam memberikan penghargaan yang signifikan sebesar 2,73\% atas kinerja perusahaan mengelola risiko lingkungan. Sebagaimana yang disampaikan oleh Bagella, Becchetti, \& Andriani (2005), rasio PER yang tinggi menunjukkan tingginya ekspektasi pelaku pasar modal terhadap laba perusahaan di masa datang (future atau transitory earnings). 
Table 3 All Countries - Accounting-based Performances

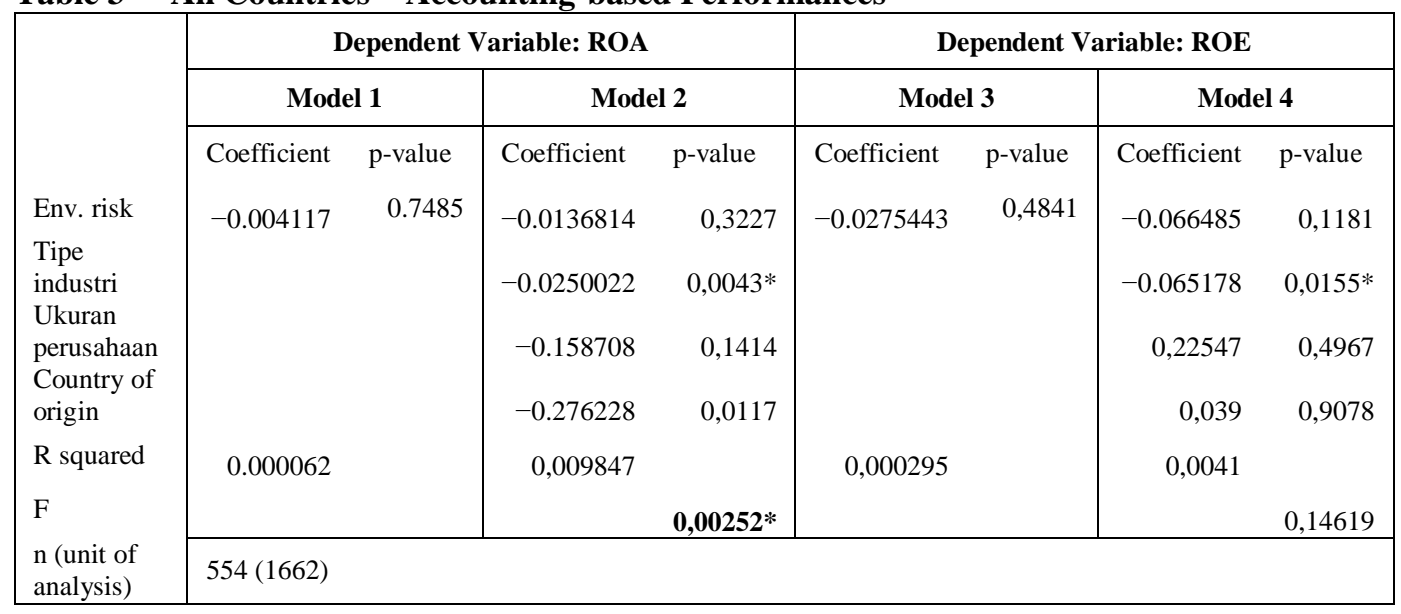

Table 4 All Countries - Market-based Performances

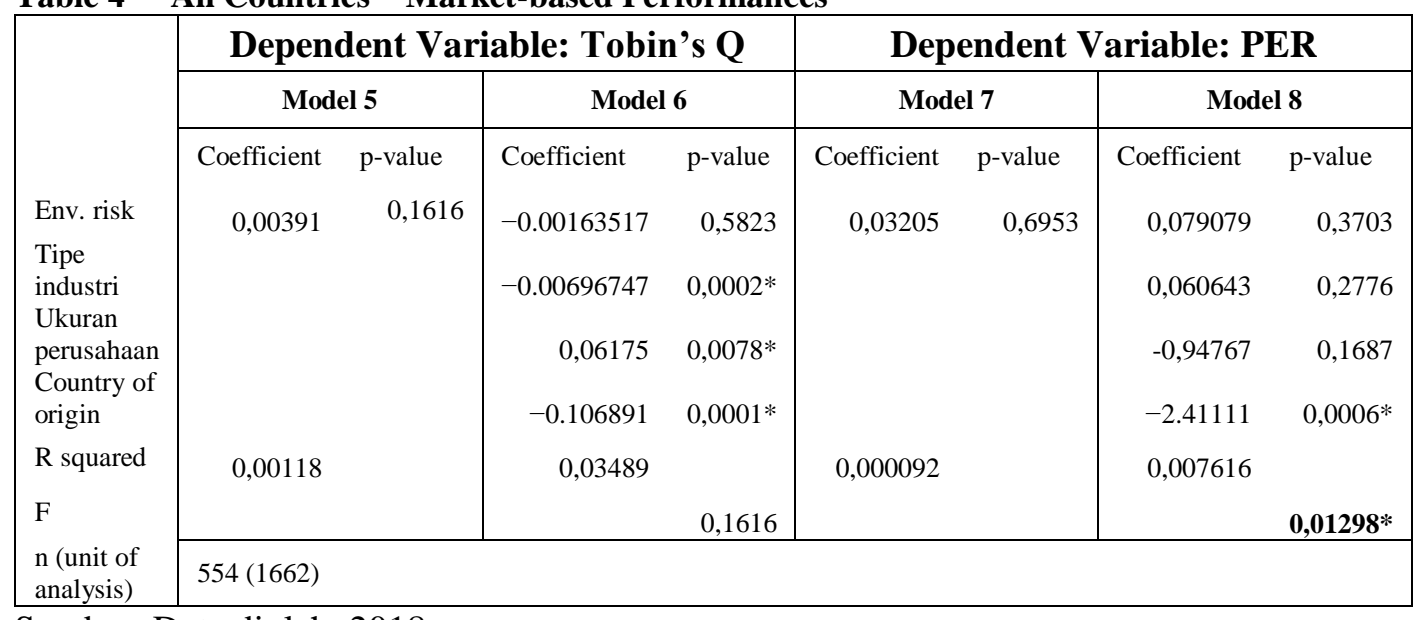

Sumber: Data diolah, 2018

Table 5 Ringkasan pengaruh signifikan environmental risk secara parsial \& simultan

\begin{tabular}{|c|c|c|c|c|}
\hline No & Negara & Model & Variabel dependen & Hasil uji \\
\hline 1 & Indonesia & 6 & Tobin's Q & $\begin{array}{c}\text { Secara parsial environmental risk berpengaruh tidak signifikan \& negative, ukuran } \\
\text { perusahaan signifikan }\end{array}$ \\
\hline 2 & Singapore & 2 & ROA & $\begin{array}{l}\text { Secara parsial environmental risk berpengaruh tidak signifikan \& positif, tipe industri } \\
\text { signifikan }\end{array}$ \\
\hline 3 & Malaysia & 4 & ROE & $\begin{array}{c}\text { Secara parsial environmental risk berpengaruh tidak signifikan \& negative, tipe industri } \\
\text { signifikan }\end{array}$ \\
\hline 4 & Malaysia & 6 & Tobin's Q & $\begin{array}{c}\text { Secara parsial environmental risk berpengaruh tidak signifikan \& negative, tipe industri } \\
\text { signifikan }\end{array}$ \\
\hline 5 & Thailand & 2 & ROA & $\begin{array}{c}\text { Secara parsial environmental risk berpengaruh tidak signifikan \& positif, ukuran } \\
\text { perusahaan signifikan \& negative }\end{array}$ \\
\hline 6 & Thailand & 6 & Tobin's Q & $\begin{array}{l}\text { Secara parsial environmental risk berpengaruh tidak signifikan \& positif, ukuran } \\
\text { perusahaan signifikan \& negative }\end{array}$ \\
\hline 7 & Thailand & 8 & PER & $\begin{array}{c}\text { Secara parsial environmental risk berpengaruh tidak signifikan \& positif, tipe industri dan } \\
\text { ukuran perusahaan berpengaruh signifikan \& positif }\end{array}$ \\
\hline 8 & Vietnam & 4 & ROE & $\begin{array}{c}\text { Secara parsial environmental risk berpengaruh tidak signifikan \& negative, ukuran } \\
\text { perusahaan berpengaruh signifikan \& positif }\end{array}$ \\
\hline 9 & Vietnam & 7 & PER & Environmental risk berpengaruh signifikan \& positif \\
\hline 10 & Vietnam & 8 & PER & Secara parsial environmental risk berpengaruh signifikan \& positif \\
\hline 11 & All countries & 2 & ROA & $\begin{array}{l}\text { Secara parsial environmental risk berpengaruh tidak signifikan \& negative, tipe industri dan } \\
\text { negara asal berpengaruh signifikan \& negative }\end{array}$ \\
\hline 12 & All countries & 6 & Tobin's Q & $\begin{array}{l}\text { Secara parsial environmental risk berpengaruh tidak signifikan \& negative, tetapi tipe } \\
\text { industri, ukuran perusahaan dan negara asal berpengaruh signifikan \& negative }\end{array}$ \\
\hline 13 & All countries & 8 & PER & $\begin{array}{c}\text { Secara parsial environmental risk berpengaruh tidak signifikan \& positif, negara asal } \\
\text { berpengaruh signifikan \& negative }\end{array}$ \\
\hline
\end{tabular}


Temuan adanya pengaruh environmental risk terhadap kinerja finansial berbasis pasar di Vietnam ini menarik. Diduga, adanya pengaruh tersebut merupakan dampak dari berbagai aktifitas berbasis sustainability program di Vietnam yang didorong oleh the Vietnam Business Council for Sustainable Development (VBCSD) memiliki kontribusi untuk membentuk persepsi pasar yang baik atas kinerja perusahaan menjalankan program berbasis sustainable business (https://en.vbcsd.vn).

Pengelolaan lingkungan yang baik
mestinya berdampak pada pencapaian
profitabilitas perusahaan yang lebih baik (de
Burgos-Jimenez et al., 2013). Hal ini karena
berbagai upaya pelestarian lingkungan pada level
perusahaan bisnis adalah bagian dari proses bisnis,
bukan sebagai beban tambahan.

Akan tetapi, hasil penelitian ini menunjukkan bahwa data risiko lingkungan tidak berkontribusi pada pencapaian kinerja keuangan secara individual. de Burgos-Jimenez et al. (2013) mengungkapkan jika aktifitas pengelolaan lingkungan mampu mencapai efektifitas dan efisiensi yang ditargetkan, maka hubungan antara kinerja lingkungan dan kinerja keuangan akan seiring sejalan (matched). Bisa jadi, manajemen memiliki perilaku kurang mendukung program pelestarian lingkungan, tidak melakukan sosialisasi kegiatan dengan memadai, serta memiliki keterbatasan tacit knowledge untuk mewujudkan tata kelola lingkungan yang memadai. Uraian ini dapat menjelaskan mengapa hasil penelitian menunjukkan bahwa secara individual environmental risk tidak berpengaruh nyata pada pencapaian kinerja keuangan perusahaan..

Hasil penelitian menjelaskan bahwa environmental risk tidak dapat berpengaruh pada accounting-based financial performance secara individual. Menurut Christmann (2000) strategi lingkungan atau environmental strategy bersifat proaktif yang dilakukan perusahaan pada akhirnya dapat menyebabkan terjadinya kenaikan profitabilitas perusahaan. Istilah yang digunakan Russo \& Fouts (1997) untuk menunjukkan strategi proaktif ini adalah systemic strategy, dimana perusahaan merancang aktifitas bisnis sedemikian rupa sehingga secara komprehensif semua lini perusahaan berorientasi pada upaya pencegahan, menjalankan efisiensi sumber daya produksi dan menjalankan program efisiensi yang inovatif untuk melestarikan lingkungan. Hasil penelitian ini menunjukkan bahwa dampak strategi proaktif tersebut hanya bisa dilihat nyata jika mempertimbangkan variabel kontrol. Untuk kasus di Asia Tenggara, faktor kemampuan manajemen untuk mengelola environmental risk saja ternyata belum mampu meningkatkan profitabilitas berbasis akuntansi perusahaan.

\subsection{Pengaruh environmental risk secara simultan terhadap financial performance (kontribusi variabel kontrol)}

Dalam penelitian ini, environmental risk bersama-sama dengan variabel kontrol mampu mempengaruhi ROA di perusahaan sampel di Singapura dan Thailand, tetapi tidak berpengaruh di empat negara lainnya. Sementara, hasil pengujian $\mathrm{H}_{4}$ menunjukkan bahwa environmental risk secara multivariate dengan variabel kontrol berpengaruh secara nyata pada ROE di perusahaan sampel di Malaysia dan Vietnam saja.

Pengujian $\mathrm{H}_{6}$ tentang pengaruh environmental risk secara simultan dengan variabel kontrol terhadap PER menunjukkan hasil bahwa variabel independen tersebut berpengaruh secara nyata di Thailand dan Vietnam saja, dan tidak berpengaruh signifikan di perusahaan sampel di Indonesia, Singapura, Malaysia, dan Filipina. Selanjutnya, pengujian $\mathrm{H}_{8}$ dengan menggunakan variabel terikat berupa Tobin's Q menunjukkan hasil bahwa environmental risk berpengaruh nyata secara bersama-sama dengan variabel kontrol untuk perusahaan di Indonesia, Malaysia, dan Thailand. Hasil pengujian $\mathrm{H} 9$ menunjukkan bahwa terdapat pengaruh nyata variabel environmental risk secara multivariate terhadap ROA. Di antara tiga variabel kontrol yang digunakan dalam persamaan regresi, hanya variabel tipe industri yang terbukti secara nyata berkontribusi pada ROA. Hal ini mengindikasikan bahwa kinerja pengelolaan lingkungan berkaitan dengan unsur biaya lingkungan. Efisiensi biaya lingkungan akan berdampak pada perolehan laba setelah pajak atas investasi yang telah ditanamkan.

Hasil uji $\mathrm{H}_{10}$ menyebutkan bahwa data gabungan seluruh negara tidak mampu 
membuktikan adanya pengaruh environmental risk, bersama-sama dengan variabel kontrol yaitu tipe industri, ukuran perusahaan dan negara terhadap ROE di seluruh negara ASEAN. Dari pengujian ini, variabel kontrol yaitu tipe industri secara parsial terbukti berpengaruh signifikan terhadap ROE. Hal ini menunjukkan bahwa tipe industri memiliki karakter yang berbeda untuk pengelolaan lingkungannya. Dengan demikian, ketika mengkorelasikan kinerja pengelolaan lingkungan dengan kinerja keuangan, investor perlu memperhatikan dari industri mana perusahaan tersebut beroperasi.

Selanjutnya, pada pengujian $\mathrm{H}_{11}$, peneliti menemukan bahwa data gabungan seluruh negara mampu membuktikan adanya pengaruh nyata atau signifikan variabel environmental risk, bersamasama dengan variabel kontrol yaitu tipe industri, ukuran perusahaan dan negara terhadap PER. Sementara, tidak terdapat bukti nyata bahwa environmental risk secara individual berpengaruh terhadap PER dengan data dari 6 negara ASEAN. Dari tiga variabel kontrol, hanya asal negara (country of origin) yang terbukti secara signifikan berkontribusi untuk menjadikan environmental risk berpengaruh signifikan terhadap PER. Hal ini mengindikasikan bahwa setiap negara memiliki struktur sosial, hukum, dan budaya yang membentuk sistem institusi sedemikian rupa sehingga dapat mendorong tingkat kesadaran masyarakat dan perusahaan bisnis untuk melakukan program-program pelestarian lingkungan hidup. Investor pasar modal menyadari tentang program tersebut dan memberikan apresiasi berbentuk kenaikan harga saham dibandingkan dengan laba per lembar saham.

Hasil pengujian pada $\mathrm{H}_{12}$ menunjukkan bahwa data gabungan seluruh negara tidak mampu membuktikan adanya pengaruh environmental risk, bersama-sama dengan variabel kontrol yaitu tipe industri, ukuran perusahaan dan negara terhadap Tobin's Q di seluruh negara ASEAN. Dari pengujian ini, variabel kontrol yaitu tipe industri, ukuran perusahaan dan country of origin secara parsial terbukti berpengaruh signifikan terhadap Tobin's Q.

\subsection{Accounting-based Vs market-based financial performance}

Hasil penelitian ini menunjukkan bahwa investor di Indonesia, Malaysia, Thailand, dan Vietnam memiliki pandangan positif dan mencari profit dari perusahaan yang memiliki kesadaran terhadap isu-isu lingkungan (environmental awareness), sebagaimana yang dinyatakan oleh Coulson \& Dixon (1995). Hal ini terbukti dari adanya pengaruh signifikan environmental risk terhadap market-based financial performance, dengan proksi PER dan Tobin's q di beberapa negara ASEAN dalam penelitian ini. Menurut Coulson \& Dixon (1995), preferensi investor pada perusahaan tertentu ini memuncukan green opportunity stock dan ethical investment. Dengan demikian, perusahaan yang tidak memiliki kebijakan berwawasan lingkungan akan mendapat kesulitan pendanaan terutama pendanaan dari pasar modal. Sebaliknya, dengan semakin banyaknya investor yang mempertimbangkan lingkungan sebagai bagian integral dari keputusan investor, maka perusahaan akan semakin terdorong untuk mengintegrasikan upaya preservasi lingkungan hidup dalam kebijakan bisnis. Penelitian ini menunjukkan bahwa kinerja lingkungan perusahaan, yang diukur dengan tingkat risiko lingkungan atau environmental risk score, direspon oleh investor. Ini dibuktikan dengan adanya pengaruh variabel environmental risk terhadap PER dan Tobin's q.

Hasil uji model OLS dengan variabel terikat berupa kinerja akuntansi, diwakili oleh ROA, menunjukkan bahwa perusahaan belum dapat mencapai keuntungan biaya (cost advantage) dengan dikeluarkannya biaya untuk pengelolaan dampak lingkungan. Tetapi, hasil penelitian ini menunjukkan bahwa environmental risk berpengaruh signifikan terhadap ROA dan bertanda negatif. Artinya, terdapat hubungan berlawanan antara kinerja perusahaan dalam mengelola risiko lingkungan dengan kinerja keuangan berbasis akuntansi. Semakin tinggi risiko lingkungan berdampak pada semakin rendahnya ROA, demikian sebaliknya.

\section{KESIMPULAN}

Penelitian ini dimaksudkan untuk mengetahui bagaimana pengaruh environmental risk terhadap profitabilitas dan nilai perusahaan yang terdaftar 
secara public di bursa efek di Indonesia, Malaysia, Singapura, Thailand, Filipina, dan Vietnam. Berikut adalah kesimpulan dari pengujian terhadap 12 hipotesis dalam penelitian ini.

1. Data tidak mampu membuktikan adanya pengaruh nyata environmental risk secara individual terhadap ROA perusahaan sampel di Indonesia, Malaysia, Singapura, Thailand, Filipina dan Vietnam.

2. Data mampu membuktikan adanya pengaruh nyata environmental risk secara bersamasama dengan variabel kontrol yaitu tipe industri dan ukuran perusahaan terhadap ROA hanya di Singapura dan Thailand. Sementara, di keempat negara lainnya, environmental risk tidak berpengaruh terhadap ROA meskipun variabel kontrol dimasukkan dalam model regresi yang diuji. Untuk kasus di Thailand, variabel kontrol ukuran perusahaan secara parsial berkontribusi pada terjadinya pengaruh secara simultan variabel environmental risk dan variabel kontrol terhadap ROA. Sementara, untuk kasus di Singapura, variabel kontrol yang berkontribusi nyata adalah tipe industri.

3. Data tidak mampu membuktikan adanya pengaruh nyata environmental risk secara individual terhadap ROE perusahaan sampel di Indonesia, Malaysia, Singapura, Thailand, Filipina dan Vietnam.

4. Data mampu membuktikan adanya pengaruh nyata environmental risk secara bersamasama dengan variabel kontrol yaitu tipe industri dan ukuran perusahaan terhadap ROE hanya di Malaysia dan Vietnam. Sementara, di keempat negara lainnya, environmental risk tidak berpengaruh terhadap ROE meskipun variabel kontrol dimasukkan dalam model regresi yang diuji.

5. Data mampu membuktikan adanya pengaruh nyata environmental risk secara individual terhadap PER pada sampel perusahaan di Vietnam. Sementara, di keempat negara lainnya, environmental risk tidak terbukti dapat mempengaruhi PER secara nyata.

6. Data mampu membuktikan adanya pengaruh nyata environmental risk secara bersamasama dengan variabel kontrol yaitu tipe industri dan ukuran perusahaan terhadap PER hanya pada perusahaan sampel di Thailand dan Vietnam. Sementara, di keempat negara lainnya, environmental risk tidak berpengaruh terhadap PER meskipun variabel kontrol dimasukkan dalam model regresi yang diuji. Antara kasus Thailand dan Vietnam terdapat perbedaan peran variabel environmental risk. Di kasus Vietnam, pada model regresi multivariate, secara parsial dan simultan variabel environmental risk berpengaruh terhadap PER. Sementara, hal ini tidak terjadi pada kasus Thailand. Pada pengujian model regresi multivariate di Thailand, variabel environmental risk secara parsial tidak berpengaruh nyata terhadap PER. Akan tetapi, hasil pengujian secara simultan menunjukkan adanya pengaruh tersebut.

7. Data tidak mampu membuktikan adanya pengaruh nyata environmental risk secara individual terhadap Tobin's Q pada kasus perusahaan-perusahaan di Indonesia, Malaysia, Singapura, Thailand, Filipina dan Vietnam.

8. Data mampu membuktikan adanya pengaruh nyata environmental risk secara bersamasama dengan variabel kontrol yaitu tipe industri dan ukuran perusahaan terhadap Tobin's Q hanya di Indonesia, Malaysia dan Thailand. Sementara, di ketiga negara lainnya, environmental risk tidak berpengaruh terhadap Tobin's Q meskipun variabel kontrol dimasukkan dalam model regresi yang diuji. Pada kasus di Indonesia dan Thailand, variabel kontrol ukuran perusahaan berkontribusi signifikan untuk mempengaruhi Tobin's Q secara simultan. Sementara untuk kasus di Malaysia, variabel kontrol yang berkontribusi nyata adalah tipe industri.

9. Data gabungan seluruh negara mampu membuktikan adanya pengaruh nyata atau signifikan variabel environmental risk, bersama-sama dengan variabel kontrol yaitu tipe industri, ukuran perusahaan dan negara terhadap ROA. Sementara, tidak terdapat bukti nyata bahwa environmental risk secara individual berpengaruh terhadap ROA dengan data dari 6 negara ASEAN. Dari tiga variabel kontrol, hanya tipe industri yang terbukti secara signifikan berkontribusi untuk 
menjadikan environmental risk berpengaruh signifikan terhadap ROA.

10. Data gabungan seluruh negara tidak mampu membuktikan adanya pengaruh environmental risk, bersama-sama dengan variabel kontrol yaitu tipe industri, ukuran perusahaan dan negara terhadap ROE di seluruh negara ASEAN. Dari pengujian ini, variabel kontrol yaitu tipe industri secara parsial terbukti berpengaruh signifikan terhadap ROE.

11. Data gabungan seluruh negara mampu membuktikan adanya pengaruh nyata atau signifikan variabel environmental risk, bersama-sama dengan variabel kontrol yaitu tipe industri, ukuran perusahaan dan negara terhadap PER. Sementara, tidak terdapat bukti nyata bahwa environmental risk secara individual berpengaruh terhadap PER dengan data dari 6 negara ASEAN. Dari tiga variabel kontrol, hanya asal negara (country of origin) yang terbukti secara signifikan berkontribusi untuk menjadikan environmental risk berpengaruh signifikan terhadap PER.

12. Data gabungan seluruh negara tidak mampu membuktikan adanya pengaruh environmental risk, bersama-sama dengan variabel kontrol yaitu tipe industri, ukuran perusahaan dan negara terhadap Tobin's Q di seluruh negara ASEAN. Dari pengujian ini, variabel kontrol yaitu tipe industri, ukuran perusahaan dan country of origin secara parsial terbukti berpengaruh signifikan terhadap Tobin's Q.

Penelitian ini memiliki kelemahan yaitu tidak memberikan informasi secara detail tentang apakah industri di mana perusahaan beroperasi berada dalam situasi sedang bertumbuh atau tidak. Russo \& Fouts (1997) menyatakan bahwa pertumbuhan industri berdampak pada profitabilitas perusahaan karena dalam konteks discounted cash flow, tingkat pertumbuhan industri mampu meningkatkan probabilitas realisasi return yang diharapkan (expected probabilities of return), mengingat tingkat penerimaan yang diharapkan (expected payoff) dari investasi yang berisiko cenderung lebih besar pada industri yang sedang bertumbuh. Menurut mereka, perusahaan yang bergerak pada industri yang sedang berkembang pesat (high-growth industri) dan mengeluarkan dana yang besar untuk membiayai kebijakan pencegahan polusi misalnya, maka perusahaan cenderung akan memiliki potensi return yang lebih besar. Penelitian selanjutnya dapat membedakan tipe industri berdasarkan pada tingkat pertumbuhannya agar dapat memahami lebih detail tentang bagaimana tipe industri dapat berkontribusi terhadap profitabilitas.

\section{REFERENSI}

Coulson, A. B., \& Dixon, R. (1995). Environmental risk and management strategy: the implications for financial institutions. International Journal of Bank Marketing, 13(2), 22-29.

Christmann, P. (2000, August). Effects of "Best Practices" of environmental management on cost advantage: The role of complementary assets. The Academy of Management JOurnal, 43(4), 663-680.

de Burgos-Jimenez, J., Vazquez-Brust, D., PlazeUbeda, J. A., \& Dijkshoorn, J. (2013). Environmental protection and financial performance: An empirical analysis in Wales. International Journal of Operations \& Production Management, 33(8), 9811018.

Man, L. W. (2010). Corporate environmentalism and environmental strategies: The relationship between resources, capabilities, strategies and performance in China's Pearl River Delta. The Hong Kong Polytechnic University, Department of Management and Marketing. Hong Kong: The Hong Kong Polytechnic University.

Russo, M. V., \& Fouts, P. A. (1997, June). A resource-based perspective on corporate environmental performance and profitability. The Academy of Management Journal, 40(3), 543-559.

Said, A. A., HassabElnaby, H. R., \& Wier, B. (2003). An empirical investigation of the performance consequences of nonfinancial measures. Journal of Management Accounting Research, 15, 193-223.

Wong, A. (2014). Corporate sustainability through non-financial risk management. Corporate Governance, 14(4), 575-586. 